single-handed on new experiments which resulted in the publication of one of his most important papers, on the energy liberation and the heat produced during shortening of active muscle. At the same time, he served as Biological Secretary of the Royal Society and on numerous scientific committees, and took a leading part in helping refugee scientists.

During the 1939/45 war he was Member of Parliament for Cambridge University, and he served as Scientific Adviser to the Government of India in 1943-44. To name only some of his other extramural activities, he served the Physiological Society, on its Committee, and as an Officer and Editor of its Journal, for 25 years, was Foreign Secretary of the Royal Society, Secretary General of the International Council of Scientific Unions, President of the British Association in 1952 when he gave his memorable address on 'The Ethical Dilemma of Science', and Chairman of the Society for the Protection of Science and Learning. A.V. gave a powerful stimulus to the study of marine biology in this country. $\mathrm{He}$ was President of the Marine Biological Association, and he constantly encouraged his younger colleagues to work at Plymouth and take advantage, not only of its delightful surroundings, but of the unique opportunities for experiments provided by the marine fauna. This initiative, together with his fascinating Liversidge Lecture on 'Chemical Wave Transmission in Nerve' helped to attract a number of distinguished biologists to the Plymouth Laboratory which later on led to very striking developments in the neurophysiological field.

A.V. was honoured by academic institutions all over the world; he was made a Companion of Honour in 1946 and received high honours from the Governments of France and the United States. At the age of 31 he was elected to the Royal Society who later awarded him the Royal and Copley Medals, and he received the 1922 Nobel Prize for Physiology together with Otto Meyerhof.

$\mathrm{He}$ is remembered and held in affection by all his pupils, not only as a great scientist who imparted to them the joy and spirit of adventure in doing experiments, but as a man who gave an example of uncompomisingly straight dealing, in the laboratory as well as outside. The pursuit of truth was to him not simply a scientific exercise, confined to one's work in the laboratory and presentation of results; it also governed his attitude in all his actions and in his relations to other persons. He was unrelentingly critical and never ceased to probe for flaws in his own deductions or experimental approach. 'To be uncritical', he said, 'particularly of oneself and one's ideas and motives, is the first long step towards dishonesty.' Yet, he never permitted his intellectual austerity to damp his enthusiasm, and I do not believe he ever allowed the slightest doubt to arise in his mind about the importance of the work he was engaged in. This buoyancy transmitted itself to those who were associated with him and helped to carry them over periods of failure and possible frustration. A.V. liked to get a good laugh out of situations which others might have regarded as perhaps slightly embarrassing; he detected and managed to focus on the humorous side of people's failings including his own. He retained, until nearly the end, a delightful, boyish sense of humour which greatly appealed to most of his friends, though at times it may have puzzled the more seriousminded ones among them.

I shall always remember a particular occasion in 1934. I was then a medical student in Leipzig, about to take my finals and anxiously making plans to escape from a hostile environment. I came across a correspondence in Nature between A. V. Hill and Johannes Stark, a famous physicist who had become the scientific 'Gauleiter' in Nazi Germany. After the 1914-18 war, A.V. had insisted (against some initial resistance) that colleagues from Germany should be invited straight away to attended International Congresses and be made to feel welcome in the scientific community. But in 1933 he was also the first to speak out vigorously against the Hitler regime and the dismissal and persecution of Jewish scientists. $\mathrm{He}$ was promptly taken to task by Professor Stark who stated in two letters to Nature that there was no factual basis for A.V.'s critical remarks, that the Nazi Government was obliged in selfprotection to restrict the influence of certain persons and was simply engaged in lawful activities like any other respectable Government. The correspondence cnded with a short note from A.V. in which he said that monetary contributions had been received in response to his appeal for assistance to colleagues who had been driven out of Germany. He added that he was not quite certain whether the donations were the result of his own eloquence, or rather of the explanations given by Professor Stark to whom, he felt some thanks were due. The Nature correspondence gave me my first impression, from a distance, of A.V.'s personality, and I found it so attractive that I made every effort to go and work with him as soon as I could.

There will be hundreds of scientists from different continents who recall with gratitude the welcome and hos- pitality they received, not only in the laboratory in Gower Street, but from A.V. and Margaret at their home in Highgate and at 'Three Corners' in Devonshire. Last year, on his 90th birthday, well over a hundred of his friends sent him a large volume containing greetings and reminiscences, and A.V. very much enjoyed browsing through them during the remaining months of his life. There can be few scientists and teachers who have won as much affection as A.V., and I believe that his personal influence among his scientific descendants in all parts of the world is a contribution to international scientific relations, not on a large scale, but of a kind perhaps more valuable than anything that official organisations could provide.

B. Katz

\section{Roman Kozlowski}

Professor Roman Kozlowski, who died on 2 May, 1977, at the age of 88, was perhaps the most internationally honoured doyen of invertebrate palaeozoology. $\mathrm{He}$ was responsible for establishing a school of palaeontological study at Warsaw of exceptional breadth and excellence. His major contributions were on the Brachiopoda and Graptolithina, but he made some contributions on most other invertebrate fossil groups.

He was born on 2 February, 1889, ai Wloclawek, north-west of Warsaw, Poland, and in 1907 he attended the University of Freiburg, and continued his geological and biological studies at the Sorbonne where he graduated in 1910. Between 1913 and 1921 Kozlowski was Professor of Geology and Mineralogy and later Director of the School of Mines at Oruro, Bolivia. It was during this period that his early work on the Carboniferous Brachiopoda and Devonian faunas of Bolivia was mostly done. The latter field he developed for a doctoral thesis under Professor Marcellin Boule (whom he affectionately spoke of as 'mon Maitre') which he received in 1923: the monograph, published in the Annales de Paléontologie, set a new standard for palaeontological illustration by collotype.

In 1924 he returned to Poland to teach at the University of Warsaw, becoming a full Professor of Geology and Palaeontology in 1934 and Chairman of the Palaeontology Department. Then really began the progressive growth to excellence of his department. His first major subsequent work followed visits in 1925 and 1926 to the Dneiper River 
sections in Podolia. The resulting monograph Les brachiopodes gotlandien de la Podolie polonaise, has been described by Shirley as 'a source of inspiration for a generation'; but this referred to the impeccable standard set by his brachiopod descriptions, especially of their internal structures. It was seminal in another way, since it gave details of a marine sequence passing from the Silurian into the Devonian. The area has recently been critical for the international definition of the Silurian/Devonian boundary.

In 1931 he noticed that graptolites were preserved in translucent chalcedony in Tremadocian rocks of the Holy Cross Mountains, and he discovered how easily these could be extracted by dissolution in hydrofluoric acid. This led eventually to the discovery of three new groups of graptoloid, and the discovery of much new detail on the ontogeny of the dendroid graptolites, and also the development of immaculate serial sectioning techniques. It also led to the extension of the techniques to other periods and a corresponding range of contributions on other groups.

The story of the survival of Kozlowski's manuscript for his monograph on Polish Tremadocian graptoloids is a most harrowing tale. His work was completed in 1939 and the bombing of Warsaw imperilled his laboratory, so he moved the typescript, illustrations and most of the specimens to a basement below the Seismological Conservatoire: his institute was destroyed. The Conservatoire was also destoyed, but a month later he was able to enter the basement, but found it sacked, and his material missing. Several months later he found part of his original manuscript in the university ruins, and shortly after, his friend Dr Rozkowski, who was later assassinated, discovered the remainder buried under snow in a courtyard.

At the Warsaw uprising of August 1944 Kozlowski was expelled, but first he hid his manuscript in the central heating system of a private house and, although the house was ruined, he was able to rescue the manuscript in 1945. The originals for his plates were lost, but since he had taken the precaution of sending negatives of these to Paris in 1939 , he was able to publish the monograph in 1949. Immediately, this establshed a new reputation for him in the field of the graptoloids. Particularly important was the detailed case he argued for assigning this important fossil group to the Pterobranchia of the Hemichordata.

After the Second World War he returned to teaching and built up his research school again and until 1960, when he retired, he was Chairman of the Palaeontological Institute of the Polish Academy of Sciences in Warsaw. When the writer visited him in 1962 he was enthusiastically engaged in preparations for the Polish Mongolian expeditions which have led to so many valuable studies under the direction of his former student Professor KielanJaworowska.

The Geological Society of London awarded him the Wollaston Medal in 1961; he was an honorary member of many Polish and international scientific societies, an honorary graduand of the universities of Krakow, Paris and Modena, a member of the Academies of Science of Poland, Czechoslovakia, France and Colombia; he was a Polish Scientific Prize-winner of the first degree.

The most important other monuments to the work of Roman Kozlowski are the two periodicals which he founded, namely, Palaeontologica Polonica of which he edited thirty-four volumes between 1929 and 1976, and Acta Palaeontologica Polonica which he edited from 1956 to 1974 . These record the incredible breadth of research work done largely by himself and his students and research associates, and give an indication of his infectious enthusiasm for all branches of palaeobiology.

Michael House

\section{George Cotzias}

ON June 13, 1977, just 3 days before his 59th birthday George Cotzias died of lung cancer. With his untimely passing the world lost a prominent neurobiological investigator who had made a number of fundamental contributions to the field.

Born in Athens, Greece, the son of a prominent political figure, he fled to the United States in 1941 when his country was occupied during World War II. His medical education which had begun at the University of Athens was continued at Harvard where in 1943 he was awarded the MD degree. Dr Cotzias then served as a house physician on the neurological and medical services of the Massachusetts General Hospital following which he began his career in research at the Rockefeller Institute in New York City. His initial interest centred on renal function but he soon became intrigued with the biological role of trace metals in tissue metabolism particularly in regard to the nervous system.

I remember well my first contact with Dr Cotzias in the 1950s. He was working on the mechani.ms by which enzymes involved in oxidative phosphorylation were activated by manganese and how this might alter central nervous system function. I was organising a symposium on parkinsonism and invited him to discuss his work. Over a three-day period in the Ramapo Mountains of New York I came to know George's innovative and individualistic approach to science; his keen mind, his wit and gregarious yet unimposing nature.

$\mathrm{He}$ was then working at the Brookhaven National Laboratories to which he had moved in 1953 and where laboratory and clinical facilities were made available to him. Gathering a substantial team of investigators around him he began expanding his investigative program with particular interest in the biochemical mechanism underlying extrapyramidal and behavioural disorders. Stimulated by his previous work with manganese, as well as the growing body of information concerning the possible role of monoamines in melanin pigment formation, he was deeply involved in defining its role in Parkinson's disease. Though many were exploring the therapeutic value of monoamines particularly dopa in the treatment of parkinsonism, none approached it with the tenacity and courage of George Cotzias. Where others were constrained by adhering to the usual principles of therapeutics, he felt that the brain mechanisms were unique and required a more adventurous approach. The dramatic effects of reversing the symptoms of parkinsonism by giving large doses of L-dopa which were achieved by the Cotzias's group is undoubtedly one of the major milestones in the treatment of neurological disorders. Not only have literally millions with the disease benefited from its use, but the therapeutic principle has found applicability to other disorders. Despite being hailed by some as a panacea for Parkinsonism, Cotzias was the first to admit that it offered only a prolonged holiday from the symptoms and much more had to be done to effect a cure. Indeed, he devoted the last 10 years of his life to looking for more effective means of overcoming the dopamine deficiency in the brain of parkinsonians.

Dr Cotzias received many honours during his life, among which were the Albert Lasker Award in Clinical Medical Research in 1969, the Borden Award in 1972 and the Oscar B. Hunter Award from the American Society of Clinical Pharmacology and Therapeutics in 1973. His native country recognised his contributions with an Honorary Doctor of Medicine degree from the National and Kapodistrian University in Athens, and in 